\title{
Intrathalamic Route of Administration
}

National Cancer Institute

\section{Source}

National Cancer Institute. Intrathalamic Route of Administration. NCI Thesaurus. Code C128995.

Administration within the thalamus. 